\title{
Arbuscular mycorrhizal fungi and Rhizobium enhance the growth of Samanea saman (trembesi) planted on gold-mine tailings in Pongkor, West Java, Indonesia
}

\author{
LULUK SETYANINGSIH ${ }^{1, \bullet}$, FIRLI AZHAR DIKDAYATAMA ${ }^{2}$, ARUM SEKAR WULANDARI ${ }^{2}$ \\ ${ }^{1}$ Faculty of Forestry, Universitas Nusa Bangsa. Jl. Kh. Sholeh Iskandar Km 4, Bogor 16166, West Java, Indonesia. "email: luluk.setya03@gmail.com \\ ${ }^{2}$ Faculty of Forestry, Institut Pertanian Bogor. Jl. Lingkar Akademik, Kampus IPB Dramaga, Bogor 16680, West Java, Indonesia.
}

Manuscript received: 6 November 2019. Revision accepted: 18 January 2020.

\begin{abstract}
Setyaningsih L, Dikdayatama FA, Wulandari AS. 2020. Arbuscular mycorrhizal fungi and Rhizobium enhance the growth of Samanea saman (trembesi) planted on gold-mine tailings in Pongkor, West Java, Indonesia. Biodiversitas 21: 611-616. Revegetation of severely degraded lands, such as gold-mine tailings, requires comprehensive approach including the selection of appropriate tree species and the improvement of soil fertility with the application of microorganisms. This study aimed to analyze the growth of trembesi (Samanea saman (Jacq.) Merr) seedlings inoculated with Arbuscular Mycorrhizal Fungi (AMF) and rhizobial bacteria (RB) on goldmine tailings in Pongkor, Bogor, West Java, Indonesia. The AMF, RB, and mixture of AMF and RB were inoculated into S. saman seedlings and then the seedlings were grown on gold mine tailings land. Seedling growth, AMF infection and RB nodulation were observed after 12 weeks after planting. The results showed that the treatments facilitated AMF colonization by up to $20.7 \%$ and RB nodulation up to 22 nodules per plant. The inoculation of $S$. saman seedlings with AMF and RB significantly increased the growth on diameter, biomass, and root length, with values of root-to-shoot ratio of 3.1-4.3. The roots of $S$. saman seedlings were also able to penetrate the depth of the tailings solum. These results showed that AMF and RB application effectively increased the growth of $S$. saman seedlings in the gold tailings field.
\end{abstract}

Keywords: Arbuscular Mycorrhizal Fungi, seedling growth, Samanea saman, Rhizobium, tailings

\section{INTRODUCTION}

Tailings are waste materials produced by mining activities after the process of separating primary minerals, such as gold and silver, from ore. In mining activities, management of tailings is mostly carried out by submarine disposal (SMD) by placing it in tailings storage facility (TSF) which is a general method aimed to hold tailings to remain on land (ANTAM 2018). Generally, mine tailings are considered to have a negative value due to the lower organic matter content, mineral nutrients, cation exchange capacity (CEC), and microorganism activity (Wasis et al. 2011), while they have higher heavy metals concentration (Setyaningsih et al. 2017). For example, Hidayati et al. (2006) and Hilmi et al. (2018) found that lead $(\mathrm{Pb})$ contamination in gold mine tailings was 6-20 times greater than land without tailings.

The Indonesian Government Regulation No. 78 year 2010 about reclamation and post-mining emphasizes that every company that operates mining activities is required to properly manage tailings to facilitate post-mining reclamation activities. Furthermore, if the mined land is previously a forested area, the post-mining reclamation would involve reforestation activities using groups of trees to recover the vegetation. Reforestation on post-mining land requires the right selection of type of plant to increase effectiveness and success of the reclamation (Lestari et al., 2019). The selected plants are expected to adapt with extreme biophysical soil conditions while at the same time it can help in remediation processes through the improvement of physical and chemical properties, as well as biological properties of the soil.

Trembesi (Samanea saman (Jacq.) Merr.) is a species from Fabaceae family which is often recommended to be planted in revegetation activities on severely degraded lands. S. saman is known to grow on clay or on waterlogged soils with $\mathrm{pH}$ ranges from 4.7 to 8.5 . This plant is also often used as a shade for other plants, such as vanilla and cacao, as well as for shade of animals that are grazing. S. saman has also been reported to be able to absorb $\mathrm{Pb}$ through roots, as well as absorb $\mathrm{Pb}$ in the air through leaves (Dahlan 2010).

Utilization fungi (Nouri et al. 2014) as well as bacteria (Akhtar et al. 2011; Altuhaish et al. 2014) is important to enhance plant growth under unfavorable conditions. Arbuscular mycorrhizal fungi (AMF) is a symbiotic mutualist soil-fungi with the ability to provide protection against disease to the host plants, as well as it can alleviate the limitation in plant growth caused by an inadequate nutrient supply, in exchange for photosynthates (Gosling et al. 2006; Nouri et al. 2014; Berruti et al. 2016). Rhizobia are able to form symbioses with legumes, within root nodules, where atmospheric $\mathrm{N}_{2}$ fixation takes place to be converted into ammonium $\left(\mathrm{NH}_{4}^{-}\right)$, also in exchange for photosynthates (Sessitsch et al. 2002; Udvardi and Poole 2013; Wheatly et al. 2017). Therefore, rhizobia have been considered as an environmentally friendly biological fertilizer. 
Preliminary experiment showed that $S$. saman inoculated with AMF was able to grow normally on the tailings media (unpublished report). The inoculation of AMF together with Rhizobium onto host plants is expected to have even better growth than if it is solely inoculated with AMF. However, there is no existing study on the performance of $S$. saman plants inoculated with both AMF and Rhizobium grown on tailings area. The objectives of this study were: (i) to examine the colonization of AMF and Rhizobium to S. saman seedling grow on tailing area; (ii) to examine the effects of $\mathrm{AMF}$ and Rhizobium inoculation to the growth of S. saman seedling grown on tailing area.

\section{MATERIALS AND METHODS}

\section{Study area and period}

The research activities were carried out in several places in Bogor Regency, Indonesia including the greenhouse of Silviculture Department, IPB University, Dramaga, Bogor for seedling preparation and observation of root infection and nodules, while the planting of $S$. saman seedling was carried out in reclamation land of PT ANTAM Tbk UBPE Pongkor, Nanggung District, Bogor, Indonesia. Material preparation for chemical analysis of tailing was carried out at the Chemistry Laboratory of the University of Nusa Bangsa, and then the samples were analyzed at the Indonesian Center for Biodiversity and Biotechnology (ICBB) research center, Bogor, Indonesia. The study was conducted over a period of 13 months, April 2018-May 2019).

\section{Nursery preparation}

The germination of $S$. saman seed was conducted on tube sprout filled with zeolite media in 7 days. Seedlings were selected based on uniformity, healthy-looking, normal morphology, straight stems with $\pm 5 \mathrm{~cm}$ height, minimum leaves number of two strands, and free from disease. $S$. saman sprouts were then transferred to polybags filled with latosol soil obtained from the nearby area (Cikabayan, Dramaga, Bogor, West Java, Indonesia). The nursery was carried out for 6 months in Silviculture greenhouse of IPB University, Dramaga, or until plants reached an average height of $70 \mathrm{~cm}$ when the plants were ready to be transferred to the tailing field.

\section{Inoculation preparation}

AMF, Glomus manihotis, hereafter referred to AMF, was propagated using bioassay method using Sorghum bicolor as a host and zeolite as a carrier. A total of 10 grams of AMF inoculum was then inoculated twice to the seedling of $S$. saman in each polybag at the nursery, and AMF inoculation was repeated when planting in the tailings field. Rhizobia inoculant, hereafter referred to RB, contained Rhizobium sp. was inoculated during the germination of $S$. saman seeds by applying 200 grams of $\mathrm{RB}$ per $4 \mathrm{~kg}$ of seeds.

\section{Planting of seedling on tailings field \\ Location}

Planting of $S$. saman seedlings was carried out at tailings field of reclamation site in the concession area of a gold mining company located at Cikabayan, Pongkor, Bogor District, West Java Province, Indonesia at geographical position of $6^{\circ} 38^{\prime} 38^{\prime \prime} \mathrm{S} ; 106^{\circ} 34^{\prime} 36,1^{\prime \prime} \mathrm{E}$ at an altitude of above sea level. This site had a tailing thickness of 30-40 m.

\section{Planting preparation}

The experiment was carried out using Split Plot Design with 4 treatments as the main plot i.e. Control, Mycorrhiza, Rhizobium and Mycorrhiza+Rhizobium applications. There were 50 plants as replication for every treatment. Seedlings were planted in the plot according to the treatment (control plot, AMF plot, Rhizobium plot, and AMF + Rhizobium plot).
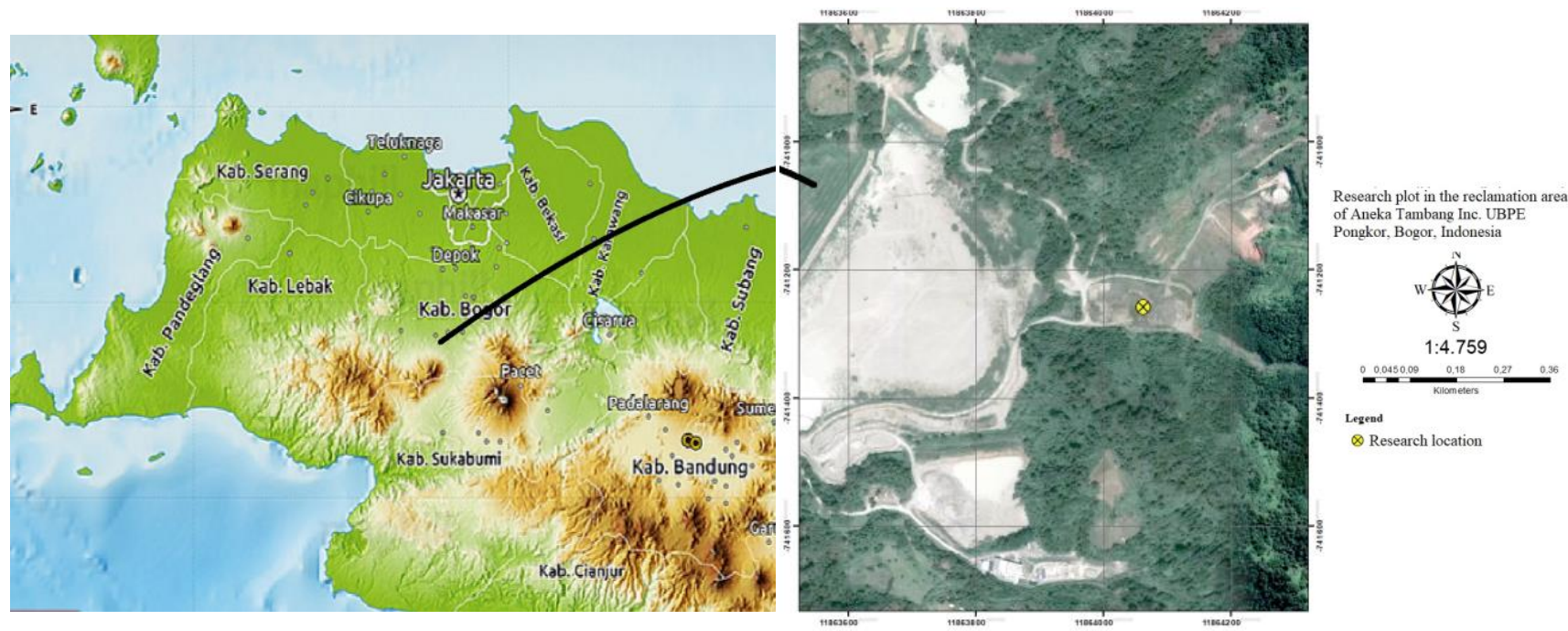
of Aneka Tambang Inc. UBPE

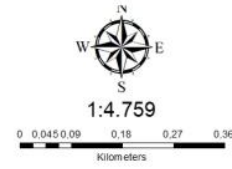

Legend

$\otimes$ Research location

Figure 1. Study location at Cikabayan reclamation area in Pongkor, Bogor District, West Java Province, Indonesia. 
Every seedling was planted in a hole of $20 \times 30 \times 30$ $\mathrm{cm}^{3}$, with $2 \times 5 \mathrm{~m}^{2}$ space among the hole. At each planting hole, $6 \mathrm{~kg}$ of compost were added as basic organic fertilizer. During the planting, a five-gram of AMF and/or Rhizobium (depended on the treatment) was applied close to the root of the seedlings, while for control treatment nothing was added. A soil mounds as high as 3-5 cm was made on each plant to prevent waterlogging. As a marker of planting, a stick was installed to each planting hole to provide treatment information and to monitor planting. Maintenance activities were carried out including watering, pests and disease control, and fertilization during the first week of planting. Observations in the field were carried out for 12 weeks.

\section{Soil analysis}

Tailing samples were taken and analyzed to observe physical (texture: sand, dust, and clay) and chemical $(\mathrm{pH}$, CCE, content of C-organic, some macronutrients: $\mathrm{N}, \mathrm{P}, \mathrm{K}$, $\mathrm{Mg}$, and a heavy metal $\mathrm{Pb}$ ) characteristics. The material preparation was conducted in Chemistry Laboratorium of Nusa Bangsa University and then they were analyzed at ICBB research center in Bogor.

\section{Growth observation}

The height of the $S$. saman seedlings in the field was measured once a week for 12 weeks. Measurements were made using a meter tape starting from the base of the stem to the bud, and from a predetermined point to the surface of the tailings. The growth of height was obtained by subtracting the final height to the initial height. Similarly, the diameter of the $S$. saman seedlings was measured once a week for 12 weeks using digital calipers on the stem at the point of the surface of the tailings. The diameter growth was obtained by subtracting the final diameter by the initial one. Plant biomass was determined at the time of harvest at 12 weeks by taking into account the dry weight of the roots and shoots of the plants (stems and leaves). The biomass was dried in the oven until it reached a constant weight, which was about 3 days. Total dry weight $\mathrm{g}^{-1}$ biomass was calculated using the formula:

Total dry weight $=($ leaf dry weight + stem dry weight $)+$ root dry weight

Before measurement, roots were washed to remove soil debris. The roots were stretched maximally, then measured the length from the root base to the tip of the root. The depth of root-penetrated solum $(\mathrm{cm})$ was determined using a spin technique to move or mobilize seedlings without damaging the roots (Hirfan 2016). The depth of the solum was measured from the surface of the tailings to the lowest root limit through the soil. The shoot to root ratio (SRR) was determined by comparing the shoot seedling dry weight with the root seedling dry weight with the formula:

$$
\text { Shoot-Root Ratio }=\frac{\text { leaves dry weight }+ \text { stem dry weight }}{\text { Root dry weight }}
$$

The criteria of SRR was analyzed based on the Alrasyid (1972) criteria that the weight of plant shoot is usually 2 to 5 times the weight of root biomass.

\section{AMF Colonization}

The percentage of root colonization was determined using the Clapp method (Nusantara et al. 2012). The root sample was washed with clean water to remove soil and plant debris. Young roots (fibers) were bleached in $20 \%$ $\mathrm{KOH}$ solution for 24-72 hours, and rinsed with water. The roots were acidified using $0.1 \mathrm{M} \mathrm{HCl}$ for 1-5 minutes until the roots were clear yellow, thereafter rinsed with water and blue stained for 2 x 24 hours. After destaining overnight, the roots were cut into $\pm 1 \mathrm{~cm}$ long, arranged on a glass object ( 1 glass object for 10 pieces of root), with every 5 pieces of root covered with glass cover, in triplicate. The percentage of AMF root colonization was calculated in terms of hyphal, vesicles and arbuscular structures, using the formula:

$$
\% \text { AMF Infection }=\frac{\text { Number of lateral root intection }}{\text { Tntal Number nf lateral ront }} \times 100 \%
$$

AMF colonization rates were categorized according to de la Cruz et al. (1999) as follows: (1) high = colonization $>40 \%$; (2) moderate = percentage of colonization $10-40 \%$;

(3) low = colonization $<10$

The number of AMF spores in the tailings media was determined using the sieving method (Nusantara et al. 2012). The efficiency of the rhizobial inoculation was evaluated taking into consideration the number of root nodules with a diameter $\geq 1 \mathrm{~cm}$, and internal reddish color.

\section{RESULTS AND DISCUSSION}

\section{Tailings properties}

Before revegetation activities, the sample of tailings in the field was taken to soil laboratory. The physical and chemical properties of the tailings on the Cikabayan reclamation area is shown in Table 1 . The content of $\mathrm{C}$ organic $(0.47 \%)$ and $\mathrm{N}$-total $(0.04 \%)$ was very low. The available phosphate $(\mathrm{P})$ content $(7.78 \mathrm{ppm})$ was low, although the potential $\mathrm{P}$ was very high $(65.75 \mathrm{mg} / 100 \mathrm{~g})$, with potassium potential $(44.95 \mathrm{mg} / 100 \mathrm{~g})$ was also high. Cation exchange capacity (4.77) was very low with very high levels of alkaline saturation while the $\mathrm{pH}$ was normal (7.42). The texture was dominated by sand (49.6\%) and dust $(33.7 \%)$ while the rest was clay. The content of heavy metal, $\mathrm{Pb},(71.55 \mathrm{ppm})$ was at normal limits.

\section{AMF colonization and rhizobial nodulation}

The percentage of AMF colonization in a single AMF treatment was categorized as low, whereas the double inoculation treatment of AMF and Rhizobium could be considered as moderate (de la Cruz et al. 1999). The double treatment of $\mathrm{AMF}+$ Rhizobium inoculation significantly increased the colonization $(\mathrm{p}<0.05)$ although the most number of AMF spores were found in seed media with only a single AMF inoculation (440 spores). Likewise, the highest number of nodules was significantly found in plants with a single Rhizobium inoculation alone (Table 2). 


\section{Growth of Samanea saman seedlings}

The growth investigation was conducted at 12 weeks after planting on tailing field. On average, transplanting to the field conditions had a survival rate of 95\% (Table 3). The height growth was not significantly different among all treatments. The application of AMF increased significantly $(\mathrm{p}<0.05)$ the diameter growth $(8.13$ $\mathrm{mm})$ and solum depth $(26.8 \mathrm{~cm})$ (Table 3 and Figure 2). The inoculation of Rhizobium did not promote the growth of the plants. Whereas, the treatments of both inoculation of AMF and Rhizobium significantly increased the growth of $S$. saman seedlings, including diameter $(8.13 \mathrm{~mm})$, dry weight $(55.75 \mathrm{~g})$ (Table 3$)$, root length $(41.88 \mathrm{~cm})$ and depth of the solum $(28.22 \mathrm{~cm})$ (Figure 2).

The shoot-to-root ratio (SSR) value of $S$. saman seedlings inoculated with AMF and Rhizobium can be seen in Figure 3. The $S$. saman seedlings planted on the Pongkor gold tailings field had SRR values of 2.05-4.31 at the age of 12 weeks after planting.

\section{Discussion}

Gold mine tailings contain very low C-organic, low cation exchange capacity, and low macronutrients. One function of organic matter is to form stable aggregates, improve cation exchange capacity, regulate immobilization and release of nutrients (Craswell and Lefroy 2001, Gruba and Mulder 2015). The soil analysis showed that the texture of three fractions (sand, dust, and clay) was dominated by sand $(49.62 \%)$, followed by dust $(33.73 \%)$, and clay $(16.65 \%)$. This fact indicates that the tailings in the study area might cause the plants underwent lacking in water and nutrient absorption. This finding clarifies Barker and Pilbeam (2015) that fine-size fractions (i.e. dust and clay) play an important role in holding water and nutrients to make them available to plants. The low value of cation exchange capacity (CEC) causes nutrients in the soil to be easily bound by heavy metal elements (Gruba and Mulder 2015; Widyatmoko 2017). In our study, this was indicated by the presence of lead metal $(\mathrm{Pb})$ which reached a concentration of $71.55 \mathrm{ppm}$. Although the $\mathrm{Pb}$ content was still within the normal range, $\mathrm{Pb}^{2+}$ concentration at $10 \mathrm{ppm}$ can cause plant stress and at the concentration of more than $100 \mathrm{ppm}$ (critical threshold) has strong potential to cause stunted growth (Barker and Pilbeam 2015). Therefore, adding compost to the tailings is very important to ensure that the plants get adequate growth media.

The application of AMF and Rhizobium in tailings significantly increased colonization by AMF in the roots, the number of nodules in the roots of the seedlings and the presence of AMF spores in the tailings rhizosphere. This finding strengthens the existing knowledge that $\mathrm{AMF}$ association with legume plants has a great influence on the development of roots and shoots and the absorption of $\mathrm{P}$ which links to the occurrence of nodulation and nitrogen fixation (Pierre et al. 2014). It is of great importance to note that microbial colonization was not found in seedlings that were not inoculated, pointing out the absence of microbiome in the tailings. On the other hand, the establishment of AMF and Rhizobium strains can be considered as indicators of the ability of introduced microbes to survive under the prevailing physico-chemical tailings conditions. Indigenous AMF strains tend to be more adaptive than foreign strains (Pierre et al., 2014). The compatibility of AMF types of Glomus manihotis and Glomus etunicatum inoculum have also been reported to be developed with jabon (Anthocephalus cadamba) seedlings on tailings media in polybags (Setyaningsih et al., 2017), as well as with Typha angustifolia (Setyaningsih et al., 2018a).

Table 1. Chemical and physical properties of tailing at Cikabayan reclamation area in Pongkor before planting

\begin{tabular}{lcl}
\hline Properties & Value & Category* \\
\hline C-organic $(\%)$ & 0.47 & Very low \\
N-total $(\%)$ & 0.04 & Very low \\
C/N ratio & 11 & Average \\
$\mathrm{P}_{2} \mathrm{O}_{5}$ available $(\mathrm{ppm})$ & 7.78 & Low \\
$\mathrm{P}_{2} \mathrm{O}$ potential $(\mathrm{mg} / 100 \mathrm{~g})$ & 65.75 & Very high \\
$\mathrm{K}_{2} \mathrm{O}$ potential $(\mathrm{mg} / 100 \mathrm{~g})$ & 44.95 & High
\end{tabular}

$\begin{array}{lrl}\text { Cation exchange (cmol (+)/kg) } & & \\ \mathrm{K}^{+} & 0.32 & \text { Low } \\ \mathrm{Na}^{+} & 0.55 & \text { Average } \\ \mathrm{Ca}^{++} & 15.7 & \text { High } \\ \mathrm{Mg}^{++} & 0.86 & \text { Low } \\ \text { Capacity of Cation Exchange }(\mathrm{cmol}(+) / \mathrm{kg}) & 4.77 & \text { Very low } \\ \text { alkaline saturation }(\%) & 100 & \text { Very high } \\ \text { pH H} \mathrm{H}_{2} \mathrm{O} & 7.42 & \text { Neutral }\end{array}$

\begin{tabular}{lll} 
Texture 3 fraction $(\%)$ & & \\
Sand & 49.62 & \\
Dust & 33.73 & \\
Clay & 16.65 & \\
Lead $(\mathrm{Pb})(\mathrm{ppm})$ & 71.55 & Normal limit \\
\hline
\end{tabular}

$*=$ Status of physical and chemical properties based on Eviati and Sulaeman (2009).

Table 2. Infection of AMF and Rhizobium to Samanea saman seedlings at 12 weeks after planting at Cikabayan reclamation area in Pongkor

\begin{tabular}{lclll}
\hline Infection & Control & AMF & RB & AMF x RB \\
\hline $\begin{array}{l}\text { Colonization (\%) } \\
\text { Spore number }\end{array}$ & $0.0^{\mathrm{a}}$ & $9.26^{\mathrm{b}}$ & - & $20.74^{\mathrm{c}}$ \\
(n/gram of soil) & $1.0^{\mathrm{a}}$ & $440.0^{\mathrm{d}}$ & $24.0^{\mathrm{b}}$ & $111.0^{\mathrm{c}}$ \\
Nodule number/plant & $24.0^{\mathrm{a}}$ & $20.0^{\mathrm{a}}$ & $52.0^{\mathrm{b}}$ & $22.0^{\mathrm{a}}$ \\
\hline
\end{tabular}

Note: Numbers followed by the different letters in the same line show significant differences based on the DMRT test with an error rate of $5 \%$

Table 3. The growth of Samanea saman seedling with AMF and Rhizobium applications 12 weeks after planting at tailing field Cikabayan reclamation area in Pongkor

\begin{tabular}{lllll}
\hline Growth & Control & AMF & RB & AMFxRB \\
\hline Survival rate $(\%)$ & $91.3^{\mathrm{a}}$ & $97.2^{\mathrm{b}}$ & $94.5^{\mathrm{a}}$ & $97.6^{\mathrm{b}}$ \\
Height $(\mathrm{cm})$ & $22.90^{\mathrm{a}}$ & $18.74^{\mathrm{a}}$ & $20.62^{\mathrm{a}}$ & $19.59^{\mathrm{a}}$ \\
Diameter $(\mathrm{mm})$ & $6.03^{\mathrm{a}}$ & $8.08^{\mathrm{b}}$ & $5.62^{\mathrm{a}}$ & $8.13^{\mathrm{b}}$ \\
Dry weight $(\mathrm{g})$ & $52.33^{\mathrm{a}}$ & $50.31^{\mathrm{a}}$ & $49.61^{\mathrm{a}}$ & $55.75^{\mathrm{b}}$ \\
\hline
\end{tabular}

Note: Numbers followed by the different letters in the same line show significant differences based on the DMRT test with an error rate 5\% 


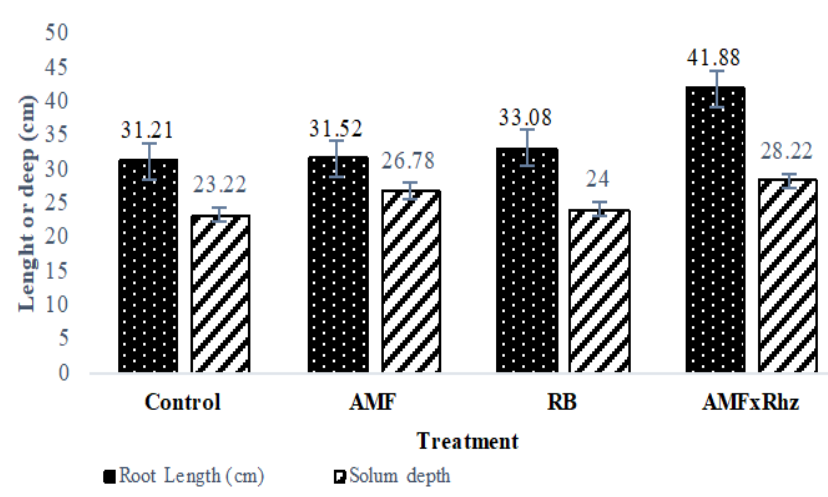

Figure 2. Root length and solum depth of Samanea saman seedling age at 12 weeks after planting at gold-mine tailing at Cikabayan reclamation area in Pongkor with various treatments of $\mathrm{AMF}$ and Rhizobium inoculations.

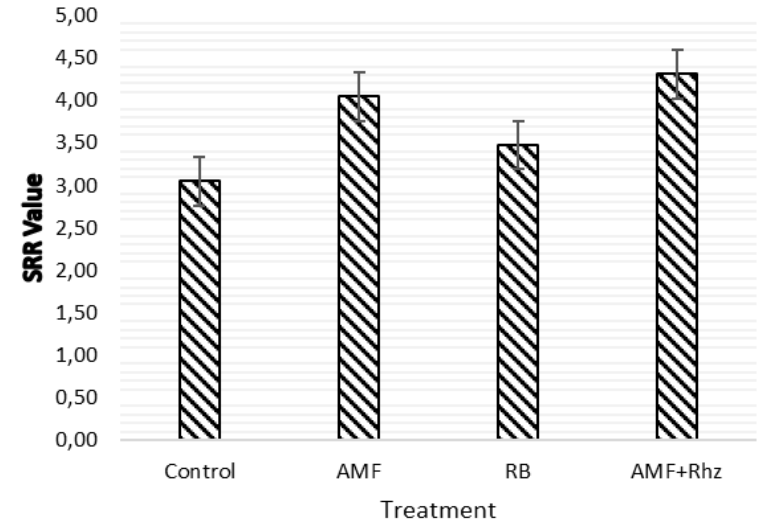

Figure 3. Shoot-to-root ratio of Samanea saman seedlings at the age 12 weeks after planting at gold mining tailing field at Cikabayan reclamation area in Pongkor with various treatments AMF and Rhizobium inoculations.
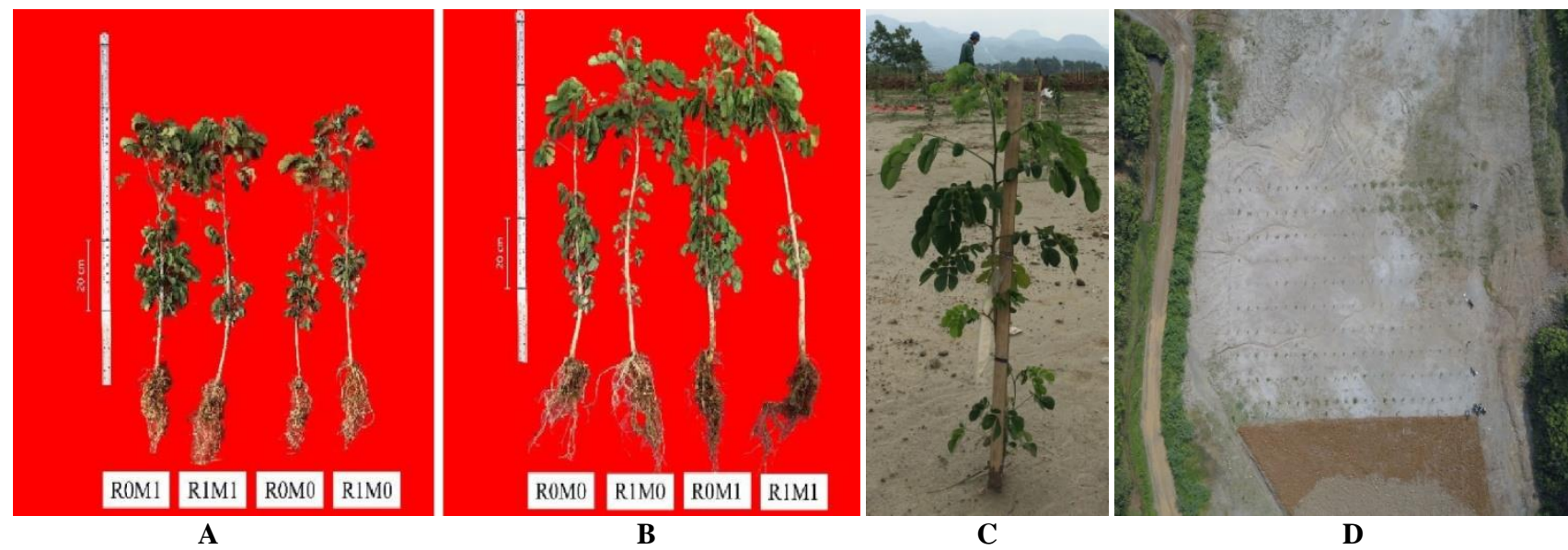

Figure 4. Performance of Samanea saman seedlings harvested at age 8 (A), age 12 (B) weeks after planting, and appearance of single seedling on the ground (C) and row of plants from the air (D) on gold mining tailing, Pongkor with various treatments AMF and Rhizobium applications. $\mathrm{R} 0=$ no Rhizobium, $\mathrm{R} 1=$ with Rhizobium, $\mathrm{M} 0=$ no $\mathrm{AMF}, \mathrm{M} 1=$ with AMF

The $95 \%$ of survival rate of S. saman was greater than that was reported for other local plant species in West Kalimantan, such as Hevea brasiliensis, Archidendron pauciflorum, Shorea leprosula and Vitex pinnata (Ekyastuti et al., 2016; Jusran 2016). The dominance of plant species and the growth rate of certain plants in a mining area, especially tailings, is strongly influenced by the level of contamination, soil physical and chemical properties, the level of plant adaptation, and other environmental factors in mine tailings (Anawar et al., 2013; Ekyastuti et al., 2016; Setyaningsih 2018b, Lestari et al., 2019), including the adaptability of plants to limit the absorption of heavy metals at the roots (Reichman 2002; Setyaningsih et al., 2012)

Dual inoculations with AMF and Rhizobium triggered a better growth of the $S$. saman seedlings than single inoculation treatment, as previously reported in a number of different plant species (Yaseen et al., 2016; Havugimana et al., 2016). AMF and Rhizobium inoculations can also play a pivotal role in increasing plant growth in areas with high heavy metal content through improved plant nutrition (Pierre et al., 2014). AMF increases nutrient and water uptake, and increases nutrient mineral transporters in plant roots, while rooted nodules fix $\mathrm{N}_{2}$ and also produce antibiotics and phytoalexin. The combination of the two microbes will provide better benefits for plants (Akhtar et al., 2011; Wang et al., 2017). However, more investigations are needed as the compatibility between the two microbes may vary, for instance between Glomus intraaridices and Rhizobium sp. NR4 strain, or between Glomus coronatum and Rhizobium sp. NR9 strain. This compatibility is important for management consideration if they are used as 
biofertilizers (Pierre et al. 2014). Results obtained in this investigation suggest the potential application of dual inoculation of $S$. saman seedlings with $\mathrm{AMF}$ and Rhizobium for the revegetation of gold mine tailing fields.

\section{ACKNOWLEDGEMENTS}

We express our deepest gratitude to The Directorate General of Higher Education, Ministry of Research and Higher Education, Republic of Indonesia with the assistance of research funding for supporting this research grant with the scheme of Applied Research, grant number: 226/SP2H/LT/DRPM/2019 or 2890/L4/PP/2019 and 0802/K4/KM/2018.

\section{REFERENCES}

Alrasyid H. 1972. Teknik Persemaian dan Penanaman. LIPI, Bogor. [Indonesian]

Akhtar MS, Siddiqui ZA, Wiemken A. 2011. Arbuscular mycorrhiza fungi and Rhizobium to control plant fungal diseases. In: Lichtfouse e (ed.). Alternative Farming Systems, Biotechnology, Drought Stress 263 and Ecological Fertilisation. Sustainable Agriculture Reviews 6. DOI 10.1007/978-94-007-0186-1_9

Anawar HM, Canha N, Santa-Regina I, Freitas MC. 2013. Adaptation, tolerance, and evolution of plant species in a pyrite mine in response to contamination level and properties of mine tailings: sustainable rehabilitation. J Soils Sediments 13: 730-741. DOI 10.1007/s11368012-0641-7.

Altuhaish A, Hamim, Tjahjoleksono A. 2014. Biofertilizer effects in combination with different drying systems and storage period on growth and production of tomato plant under field conditions. Emir J Food Agric 26 (8): 716-722.

ANTAM [PT Antam Persero Tbk]. 2018. Penambangan emas. http://www.antam.com [17 August 2018]. [Indonesian]

Berruti A, Lumini E, Balestrini R and Bianciotto V. 2016. Arbuscular mycorrhizal fungi as natural biofertilizers: Let's benefit from past successes. Front Microbiol 6: 1559. DOI: 10.3389/fmicb.2015.0155

Barker AV, Pilbeam DJ. 2015. Handbook of Plant Nutrition. 2nd ed. CRC Press, Boca Raton, FL.

Craswell ET, Lefroy EDB. 2001. The role and function of organic matter in tropical soils. Nutr Cycling Agroecosyst 61: 7-18. DOI: 10.1023/A: 1013656024633

Dahlan E. 2010. Trembesi dahulunya asing, namun sekarang tidak lagi. http://endesdahlan.staff.ipb.ac.id/ [17 August 2018]. [Indonesian]

De la Cruz RE, Zarade JF, Angganzae NS, Lorilla EB. 1999. Differentia mycorrhizal development of some agricultural, horticultural and forestry crops to inoculation of mycorrhizal fungi. Proceeding of The International Symposium on Management of Mycorrhizas in Agriculture, Horticulture and Forestry. Australian Institute of Agricultural Sciences, Perth, Sep 28-Oct 21992.

Eviati, Sulaeman. 2009. Analisis Kimia Tanah, Tanaman, Air, dan Pupuk. Balai Penelitian Tanah, Bogor. [Indonesian]

Ekyastuti, Wiwik, Astiani D, Roslinda E. 2016. Prospect of indigenous plant species for revegetation in the tailings area of ex community gold mine. Biodiversitas 17: 764-768. DOI: 10.13057/biodiv/d170252

Gruba P, Mulder J. 2015. Tree species affect cation exchange capacity (CEC) and cation binding properties of organic matter in acid forest soils. Sci Total Environ 511: 655-662. DOI: 10.1016/j.scitotenv.2015.01.013

Gosling P, Hodge A, Goodlass G, Bending GD. 2006. Arbuscular mycorrhizal fungi and organic farming. Agric Ecosys Environ 1 (4): $17-35$.

Hidayati N, Syarif F, Juhaeti T. 2006. Potensi Centrocema pubescence, Calopogonium mucunoides, dan Micania cordata dalam membersihkan logam kontaminan pada limbah penambangan emas. Biodiversitas 7 (1): 4-6. DOI: 10.13057/biodiv/d07012.

Hilmi M, Hamim H, Sulistyaningsih YC, Taufikurahman. 2018. Growth, histochemical and physiological responses of non-edible oil producing plant (Reutealis trisperma) to gold mine tailings. Biodiversitas 19 (4): 1294-1302.

Hirfan. 2016. Strategi reklamasi lahan pasca tambang. Jurnal Ilmiah IlmuIlmu Teknik 1 (1): 101-108. [Indonesian]

Jusran. 2016. Tingkat keberhasilan tumbuh tanaman sengon (Paraserianthes falcataria) dan trembesi (Samanea saman) umur 4 bulan pada lahan bekas tambang PT. BJA (Bhumiku Jadi Abadi) di Separi Kabupaten Kutai Kartanegara. Politeknik Pertanian Negeri Samarinda, Samarinda. [Indonesian]

Lestari DA, Fiqa AP, Fauziah F, Budiharta S. 2019. Growth evaluation of native tree species planted on post-coal mining reclamation site in East Kalimantan, Indonesia. Biodiversitas 20: 134-143

Nusantara AD, Bertham YH, Mansur I. 2012. Bekerja dengan Fungi Mikoriza Arbuskula. Bogor (ID): SEAMEO BIOTROP, [Indonesian]

Nouri E, Breuillin-Sessoms F, Feller U, Reinhardt D. 2014. Phosphorus and nitrogen regulate arbuscular mycorrhizal symbiosis in Petunia hybrida. PLoS ONE 9: e90841. DOI: 10.1371/journal.pone.0090841

Indonesian Regulation [Pemerintah Republik Indonesia]. 2010. Peraturan Pemerintah Republik Indonesia Nomor 78 Tahun 2010 tentang Reklamasi dan Pascatambang. Sekretariat Negara, Jakarta. [Indonesian]

Pierre, Jean M, Bhople BS, Kumar A, Erneste H, Emmanuel B, Sing YN. 2014. Contribution of arbuscular mycorrhizal fungi (AM fungi) and Rhizobium inoculation on crop growth and chemical properties of rhizospheric soils in high plants. J Agric Vet Sci (IOSR-JAVS) 7 (9): 45-55.

Reichman SM. 2002. The responses of plants to metal toxicity: A review focusing on copper, manganese and zinc. Australian Minerals \& Energy Environment Foundation, Melbourne.

Sessitsch A, Howieson JG, Perret X, Antoun H, Romero EM. 2002. Advances in Rhizobium research. Crit Rev Plant Sci 21 (4): 323-378.

Setyaningsih L, Setiadi Y, Budi SW, Sopandie D. 2012. Organic acid characteristics and tolerance of sengon (Paraserianthes falcataria $\mathrm{L}$ Nielsen) to Lead. JMHT 18 (3): 177-183. DOI: 10.7226/jtfm.18.2.177

Setyaningsih L, Setiadi Y, Budi SW, Hamim, Sopandie D. 2017 .Lead accumulation by jabon seedlings (Anthocephalus cadamba) on tailing media with application of compost and arbuscular mycorrhizal fungi. IOP Conf Ser Earth Environ Sci 58: 012053. DOI: 10.1088/17551315/58/1/012053.

Setyaningsih L, Setiadi Y, Budi SW, Hamim, Sopandie D. 2018a. Jabon (Anthocephalus cadamba Roxb) potency for remediation lead $(\mathrm{Pb})$ toxicity under nutrient culture condition. Biotropia 25 (1): 64-71. DOI: 10.11598/btb.2018.25.1.712

Setyaningsih L, Wulandari AS, Hamim H. 2018b. Growth of Typha grass (Typha angustifolia) on gold-mine tailings with application of arbuscular mycorrhizal fungi. Biodiversitas 19 (2): 454-459. DOI: 10.13057/biodiv/d190218

Udvardi MK, Poole PS. 2013. Transport and metabolism in legumerhizobia symbioses. Ann Rev Plant Biol 64: 781-805. DOI: 10.1146/annurev-arplant-050312-120235

Wasis B, Sandrasari A. 2011. Pengaruh penambahan pupuk kompos terhadap pertumbuhan semai mahoni (Swietenia macrophylla King.) pada media tanah bekas tambang emas (tailing). Jurnal Silvikultur Tropika 3 (1): 109-112. [Indonesian]

Wang WX, Shi JC, Xie QJ, Jiang YN, Yu N, Wang ET. 2017. Nutrient exchange and regulation in arbuscular mycorrhizal symbiosis. Mol Plant 10: 1147-1158. DOI: 10.1016/j.molp.2017.07.012

Widyatmoko. 2017. Laju penyerapan N dan P limbah kultivasi ikan oleh akar wangi (Vetiveria zizanioides L. Nash) dalam sistem resirkulasi. [Tesis]. Institut Pertanian Bogor, Bogor. [Indonesian]

Wheatly RM. Ramachandran WVK, Geddes BA, Perry BJ, Yost CK, Poole PS. 2017. Role of $\mathrm{O}_{2}$ in the growth of Rhizobium leguminosarum bv. viciae 3841 on glucose and succinate. J Bacteriol 199 (1): e00572-16. DOI: 10.1128/JB.00572-16

Yaseen T, Ali K, Maunsif F, Rab A, Masood A, Israr M, Baraich AK. 2016. Influence of arbuscular mycorrhizal fungi, Rhizobium inoculation. Pak J Bot 48 (5): 2101-2107. 